\title{
Türkiye İçin Bir Taşınmaz Değerleme Sistemi Yaklaşımında Temel Veri Yönetimi
}

\author{
Nuri ERDEM ${ }^{*}$ \\ ${ }^{1}$ Osmaniye Korkut Ata Üniversitesi, Mühendislik Fakültesi, Harita Mühendisliği Bölümü, Osmaniye \\ (nurierdem@oku.edu.tr)
}

$\ddot{O} \mathbf{z}$

Taşınmaz değerlemesi alanında gelişmiş sistemlere sahip ülkelerde olduğu gibi, ülkemizde de değerleme çalışmaları sırasında ihtiyaç duyulan verilere erişilebilmesi ve çalışmaların sağlıklı bir altyapı çerçevesinde gerçekleştirilebilmesi için, taşınmaz karakteristikleri ve taşınmaz piyasasındaki gerçek alım-satım değerleriyle ilgili bilgileri içeren emsal satışlar veritabanları kurulmalıdır. Taşınmaza ait bilgilerin ortak bir veritabanından elde edilebilmesi, değerleme uzmanlarının ihtiyaç duydukları verilere daha kısa sürede ve kolayca ulaşabilmesini sağlayacaktır. Bu çalışmada, ülkemiz için önerilen Türkiye Taşınmaz Değerleme Sistemi (TADES) yaklaşımının temel veri yönetimi, teknik özellikleri ve ilgili alandaki mevcut bazı teknik sorunların çözüm önerileri üzerinde durulmaktadır.

Anahtar Kelimeler: Değerleme Sitemi, Veritabanı Yönetimi, Veri Modeli, CBS.

\section{Basıc Data Management In An Approach For Turkısh Real Estate Valuation System}

\begin{abstract}
Similar sales records databases should be established in Turkey as well as in countries with developed systems in the field of immovable valuation so that the required data can be accessed during the valuation studies and the studies can be carried out within a healthy infrastructure with information about the real estate properties and the actual purchase and sale values in the immovable market. The ability to obtain information from the immovable property from a common database will enable valuation specialists to access the information they need in a shorter period of time. This study focuses on the basic data management, technical characteristics and proposals for solutions of some existing technical problems in Turkey, which are recommended for Turkey by the Turkish Real Estate Valuation System (TADES) approach.
\end{abstract}

Keywords: Valuation System, Database Management, Data Model, GIS.

\footnotetext{
* Sorumlu Yazar

Bu makale; Yük. Müh. Nuri ERDEM'in 2016 yılında Erciyes Üniversitesi Fen Bilimleri Enstitüsü Harita Mühendisliği Anabilim Dalında tamamlanan "Türkiye İçin Bir Taşınmaz Değerleme Sistemi Yaklaşımı" isimli doktora tez çalışmasından üretilmiştir.
} 


\section{GÍRIŞ}

Taşınmaz değerinin belirlenmesinde kesin modellerden söz etmek zordur. Her ülkenin taşınmaz değer tespitinde kendine has kültürleri, konumsal ya da bölgesel özelliklerine göre kullandıkları yöntemlerde farkl1lıklar görülebilir. Yöntemlerin çoğu emsal karşılaştırma temeline dayanmaktadır.

Model ya da yöntemler ise doğrudan kullanıcıların düşüncesini taklit ederek, piyasayı analiz etmeye çalışır (Yalpır, 2007; Pagourtzi and Assimakopoulos, 2003). Ülkemizde taşınmaz değerlemesi çalışmalarında kullanılan geleneksel değerleme yöntemleri sırasıyla karş1laştırma, maliyet ve gelir yöntemleridir (Açlar ve Çağdaş, 2008; Yalpır vd., 2002).

Gelişen teknolojiyle birlikte dünyada olduğu gibi ülkemizde de modern değerleme yöntemlerinin kullanılması zorunlu hale getirmiştir. Taşınmaz değerlemede son y1llarda tercih edilen modern değerleme yöntemleri arasında yapay sinir ağları, bulanık mantık, konumsal analiz ve destek vektör makineleri regresyonu gibi yöntemler önemli bir yer tutmaktadır.

Konumsal analiz ile değerleme yöntemi: Konumsal analiz, verilerin görsel bir biçimde coğrafi olarak sunulmasına olanak sağlayan bilgi sistemi ve ilgili yazılımların yardımı ile noktasal ve sözel verilerin anlamlı ve bilgilendirici haritalar üzerinde sunulmasıdır. Konumsal analiz ile Coğrafi Bilgi Sistemini (CBS) kullanarak taşınmaz değer tespitleri yapılmış ve bazı yöntemler ile karşılaştırılmıştır. Konumsal analiz yönteminin özellikleri aşağıda özetlenmektedir (Yalpır, 2007):

- CBS esasina dayanılarak grafik ve sözel bilgiyi birleştirerek çalışılmalıdır.

- Güncel harita altlığı ve ilişkilendirilmiş veri tabanının bulunması gerekir.

- Bazı verilerin harita altlığından elde edilmesinden dolayı süre ve maliyet açısından avantajlı bir yöntemdir.
- Verilerin güncel olarak tutulmasını gerektirir.

\section{SEÇILMIŞ BAZI ÜLKELERDE CBS DESTEKLI TAŞINMAZ DEĞERLEME ÇALISYMALARI}

Araştırma kapsamındaki ülkelerin tamamında değerleme çalışmaları sırasında Coğrafi Bilgi Sistemleri (CBS) teknolojilerinden yararlanılmaktadır. Çünkü CBS, özellikle değerleme sonuçlarının kontrolünde ve analizinde önemli bir araç olarak görülmektedir. Ancak, bu konuda resmi bir zorunluluk getirilmemiş, daha çok CBS;

- Zaman içinde (yeni yatırımlar ve projelerin etkisiyle) detaylarda yaşanan veya yaşanabilecek değişikliklerin tespitinde,

- Malikler arasındaki gerçek alım-satım fiyatları ile farklı statüdeki resmi kurumların belirlediği fiyatlar arasında oluşabilecek uyumsuzlukların belirlenmesinde,

- Takdir edilen değerlerin kalite kontrolü yapılırken, fiyat oluşumunda önemli etkileri olan çevresel ve konumsal faktör ilişkilerinin gözlemlenmesinde,

kullanılmaktadır.

\section{Hollanda}

Hollanda'da taşınmaz Değerleme çalışmalarında, zorunlu olmamakla birlikte, harita altıkları ile coğrafi bilgi sistemi (CBS) teknolojilerinden yararlanılmaktadır. $\mathrm{Bu}$ teknolojilerle zaman içindeki değişikliklerin belirlenmesi, alım satım değerlerindeki uyumsuzluklar ve biçilen değerlerin kalite kontrolü sırasında konumsal ilişkilerin gözlemlenmesi yapılabilmektedir (Köktürk ve Köktürk, 2015).

Danimarka'nın taşınmaz değerleme sistemindeki çalışmalar sırasında CBS teknolojilerinden yararlanılmaktadır. İnternet ortamından erişilebilen sistemde bir taşınmazın, bulunduğu yerin bilgileri girilerek, en son ne zaman değerlendirildiği, arazi değeri ve taşınmaz değeri gibi bilgilere ulaşılabilmektedir (HKMO, 2012). 
Malezya'da Maliye Bakanlı̆̆ı'na bağlı Gayrimenkul Değerleme Genel Müdürlüğü’nün misyonu; gayrimenkul değerleme ve danışmanlık hizmetleri sunmak, gayrimenkullerle ilgili bilgileri talep edenlere zamanında, güvenilir ve profesyonel bir şekilde sunmak olarak ifade edilmiştir. Genel Müdürlük merkezi üç ana birimden oluşmaktadır (Susar, 2007; Jahanshiri, 2011). Bunlardan birisi olan Gayrimenkul Bilgi Merkezi (National Property Information Center- NAPIC); Değerleme Bilgi Sistemi (Valuation Information System, VIS) adl bilgisayar tabanlı bir projeyi tamamlama çalışmalarını sürdürmektedir. Sisteme dâhil birimler on-line olarak birbirleriyle bağlıdır. VIS dışında web tabanlı olarak çalışan diğer bir sistem PRISM (Property Information System Malaysia)'dır. PRISM, Coğrafi Bilgi Sistemleri (CBS) uygulamalarına da yanıt verecek bir bilgisayar sistemi olarak tasarlanmıştır (Susar, 2007; Jahanshiri, 2011).

\section{Finlandiya}

Finlandiya, TKGM Modernizasyon projesi sirasinda kurum tarafindan ziyaret edilen ülkelerdendir. Çalışma ziyareti kapsamında oluşturulan rapora göre; Ulusal Vergi Kurulu

ve Finans Bakanlığı, vergilendirme amaçlı toplu değerleme (mass valuation) işlemlerini, her beş yılda bir Finlandiya Teknik Araştırmalar Merkezi (VTT)'ne yaptırmaktadır (Şekil 1). Hazırlanan raporlar, satış fiyatı kayıtları ve yetkililerle yapılan görüşmelere dayanmaktadır. Yapılan çalıșmalar neticesinde oluşturulan CBS destekli değer haritaları ve yapılan istatistiki analizler, ülkedeki taşınmaz değerlerinin durumu hakkında bilgi üretilmesini sağlamaktadır. 30 yıllık veri arşivi değerleme çalışmalarına önemli katkı sağlamaktadır (Y1ldiz, 2014).

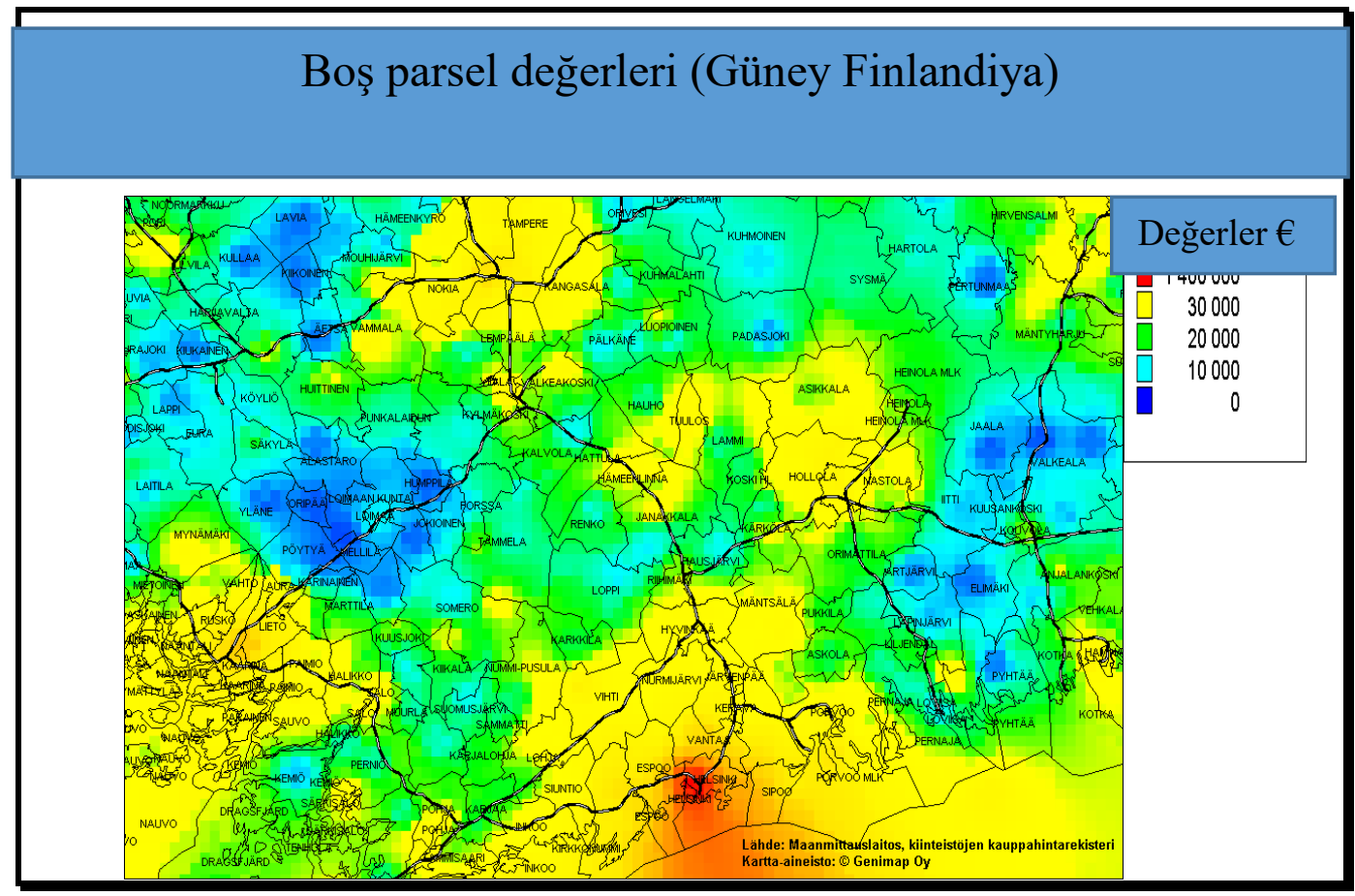

Şekil 1. Finlandiya'da VTT Tarafından Üretilen Şehir Merkezini İçeren Değer Haritası.

DEĞERLEME

SISTEMIMIZIN

YENIDEN

İLGILI

YAPILANDIRILMASIYLA YAPILMIȘ

BİLIMSEL 


\section{ÇALIŞMA VE ÖNERILERDE CBS'NIN YERI}

Ülkemizdeki taşınmaz değerleme sisteminin mevzuat, kurumsal ve teknik yapılanmasıyla ilgili bilimsel anlamda yapılmış çalışma ve önerilerden bazıları aşağıda özetlenmektedir.

Nişanc1 (2005)' göre; Değerleme çalışmalarının en önemli sonuç ürünlerinden biri CBS destekli değer haritalarıdır.
Değerleme alanında iyi uygulamaya sahip ülkelerde bu haritalar üretilmekte ve kullanıcıların hizmetine sunulmaktadır. Ülkemizde ise, bazı akademik/bilimsel çalışmalar haricinde bu alanda kapsamlı bir çalışma mevcut değildir. Şekil 2'de Nişancı (2005) tarafından gerçekleştirilen doktora çalışmasında CBS destekli üretilen İstanbul çalışma alanı sokak bazında raster nominal değer haritası örneği görülmektedir.

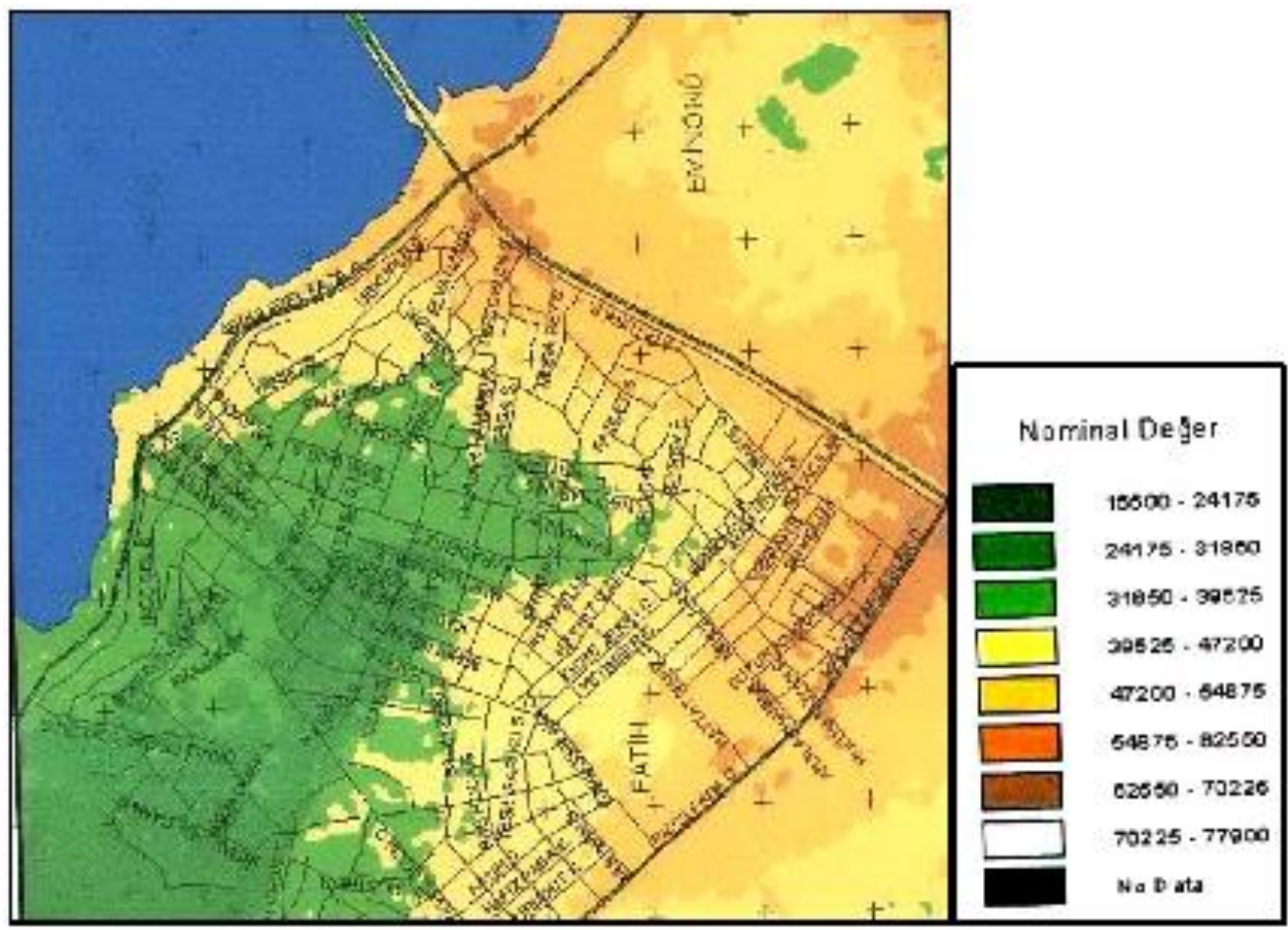

Şekil 2. İstanbul çalışma alanı sokak bazında raster tabanlı nominal değer haritası (Nişancı, 2005).

Çă̆daş (2007)'de; Toplu değerleme sistemine geçiş önerilmiş; bu amaçla süreçte görev alması olası aktörler tanımlanmış; değerlemede kullanılacak veri türleri ve verilerin edinim yolları belirlenmiş; değerleme süreci modellenmiş; diğer değerleme uygulamalarında da yararlanılacak Ulusal Değerleme Veri Tabanının kurulması önerilmiştir. Vergi tarhiyatı süreci de tanımlama ve değerleme alt sistemlerindeki önerilere göre yeniden düzenlenmiştir.

Çağatay (2008)'e göre; Türkiye'de taşınmaz değerlemesi alanında önemli bir boşluğu dolduracak olan Taşınmaz Değerlemesi Bilgi Sistemi (TADEBİS) için kurumsal ve teknik bir yapılanmaya ihtiyaç bulunmaktadır. Kurumsal açıdan taşınmaz değerlemesinden sorumlu olacak kurum, kamu kontrolünde ve özel sektör paylaşımlı olmalıdır. Örgüt yapısı olarak ise merkez ve il düzeyinde örgütlenen taşra birimlerinden oluşmalıdır. Merkez teşkilatının yönlendirici olmasının yanında değer oluşum süreçlerini taşra birimlerine birakmas1 daha uygundur. Bunun sebebi, taşınmaz piyasalarının yerel olması, değerlemeyi oluşturan verilere taşrada daha kolay ulaşılabilmesi gibi faktörlerdir. Taşınmaz değerlemesi işlemi için gerekli olan 
veriler, her ilde ayrı ayrı toplanmalı ve değerlemeyi her il için mutlaka değerleme uzmanları gerçekleştirmelidir.

Değirmenciler (2008)'e göre; Etkin bir taşınmaz değerleme sistemi için Değer İzleme Sistemi kurulmalıdır. Değer hareketlerinin anlık izlenebilmesi için gayrimenkulün bulunduğu bölgede bulunmak gerekmektedir. $\mathrm{Bu}$ yüzden değer izleme sistemi, merkezden yönetilen yerel ağların bir toplamı olmalıdır. Kurumlar arasındaki işbirliğinde; Maliye Bakanlığı, Tapu ve Kadastro Genel Müdürlüğu ve Belediyeler öne çıkmaktadır. Her ay bir ilçede oluşan değerler yerel maliye teşkilatı tarafından toplanacak ve ay sonunda merkez birime bildirilecektir. İlgili ay içinde o ilçede mahkemelerce yapılan kamulaştırma ve kira takdirleri, Hazineye ait taşınmazlara ilişkin takdirler, banka kredisine esas değer takdirleri, belediyelerin yaptığı tüm takdirler bu kapsama dahildir. Yerel maliye teşkilatı eline ulaşan bu değerleri arsa, arazi, bina ve konut anlamında ayrıştıracak ve o şekilde merkeze gönderecektir. $\mathrm{Bu}$ bilgiler CBS uyumlu bir değer haritasının oluşumuna altlık oluşturacaktır. Yerel maliye teşkilatı, o ilçede Tapu Sicil Müdürlügünde yapılan işlemleri de aylık olarak alacaktır. Değerlerin veri olarak depolanması birçok kamu kurumunun uygulamalarında yol gösterici olacaktır.

Değer İzleme Sistemi, Maliye Bakanlı̆̆1 bünyesinde kurulacak bir birim çatısı altında faaliyetlerini yürütmelidir. Çünkü Hazineye ait gayrimenkuller ve gayrimenkulden kaynaklı vergi kayı ve kaçakları düşünüldügünnde etkin maliye politikalarının geliştirilmesi anlamında tek yetkili kurum Maliye Bakanlığıdır. Sistemin etkin ve hızlı çalışabilmesi için öncelikle yerel yönetimlerin, kendilerine kanunla görev olarak verilen $\mathrm{CBS} / \mathrm{KBS}$ yatırımlarını arttırmaları, sorumluluk alanlarındaki arsa, arazi ve binalara ilișkin bilgileri bir veri bankasında sağlıklı bir şekilde depolamaları gerekmektedir.

Hacıköylü (2009)'a göre; Emlak vergisinde yaşanan değer tespitine ilişkin sorunlar mevzuattan, idareden ve mükelleften kaynaklanan sorunlardır. Mevzuattan kaynaklanan sorunların çözümü için; mülkiyet kadastrosu anlayışının terk edilerek mali kadastro anlayışının benimsenmesi gerekir. Böylece vergisel amaçlı taşınmaz değerlemesi önem kazanacak, taşınmaz satış veri tabanının oluşturulması ve CBS'nin bu açıdan kullanılması sağlanabilecektir.

Yuldiz (2014)'e göre; Kurulacak toplu değerleme sisteminden sorumlu olacak kuruluşun, veri paylaşımı konusunda sorun yaşamamas1, siyasi baskılardan etkilenmemesi gerekmektedir. $\mathrm{Bu}$ nedenle, toplu değerleme faaliyetlerinin, tekil değerleme işlemlerini de yapan, yaptıran, denetleyen, düzenleyen bir üst kurul eli ile yürütülmesi gerektiği değerlendirilmektedir. Toplu değerleme sisteminin ihtiyaç duyduğu ilk temel bileşen değer/fiyat bilgileridir. Toplu değerleme sisteminin kurulabilmesi için gereken birinci koşul satış işlemlerinde gerçekleșen fiyat bilgisinin doğru olarak, ayrıntılı bilgileri ile birlikte tutulduğu TAKBİS ile entegre ortak bir veritabanının oluşturulmasıdır. Böylece bu bilgiler toplu değerleme sistemi içinde model oluşturma amaçlı olarak kullanılabilecektir.

Toplu değerleme sisteminin ihtiyaç duyduğu ikinci temel bileşen, taşınmazların değerine etki eden öz nitelik bilgileridir. Bu verilerin, kurumlar arası veri paylaşımı ile elde edilebileceği düşünülmektedir. Verilerin yönetilmesinden sorumlu bulunan kurumların veri yapılarını, istatistiki analiz ve modelleme için ortak bir formatta ve online paylaşımına uygun hale getirmeleri ile toplu değerleme sisteminin kurulabilmesinin önü açılacaktır (Y1ldiz, 2014).

\section{TÜRKIYE TAȘINMAZ DEĞERLEME SISTEMI TEMEL VERİ YÖNETIMI}

$\mathrm{Bu}$ bölümde, ülkemiz için önerilen Türkiye Taşınmaz Değerleme Sistemi (TADES) yaklaşımının temel veri yönetimi, teknik özellikleri ve ilgili alandaki mevcut bazı 
teknik sorunların çözüm önerileri üzerinde durulmaktadir.

\section{Önerilen Yaklaşımda Veri Yönetimi}

TKGM Detaylı Pilot Eylem Planı Raporu (2014)'e göre; tüm değerleme işlemlerinde elde edilen değerlerin kalitesi, analiz için elverişli olan verilerin niteliğine ve niceliğine bağlıdır. İki tip veriye ihtiyaç duyulmaktadır: (1) değer göstergeleri ve (2) değerlenen gayrimenkullerin özelliklerini tanımlayan veriler. İhtiyaç duyulan veriler gayrimenkullerin kullanımını, boyutunu, yerini ve onları piyasada çekici ya da itici hale getiren özelliklerini tanımlayan verilerdir. $\mathrm{Bu}$ süreçte birkaç tipte değer göstergesi kullanılabilir. En kullanışı olanı açık piyasa emsal satışlardır. Çünkü bu değerler piyasa değeri tanımlamasındaki koşullara en çok uyan değerlerdir.

TADES yaklaşımında, değerleme işlemlerinden en fazla yararı sağlayabilmek amacıyla, öncelikle verilerin kaynağı, güncel, doğru, tam, kapsaml,, anlaşılabilir, kullanılabilir ve erişilebilir olmasına özel önem verilmelidir. $\mathrm{Bu}$ bağlamda, çalışma kapsamında, değerleme verilerinin kaynağ mevcudiyeti, kalitesi ve önem derecesiyle ilgili çok sayıda uzmanla, yüz yüze görüşme veya e-mail yoluyla anket çalışmaları yapılmıştır. Elde edilen sonuçlara göre (Tablo 1), taşınmaz değerlemesi için gerekli olan veriler ve veri üretiminden sorumlu olan kurumlar Şekil 3'de özet olarak gösterilmiştir.

Tablo 1. Arsa Değerlemesinde İhtiyaç Duyulan Veriler ve Genel Özellikleri.

*Önem Derecesi: 1-Çok Önemli, 2- Önemli, 3- Biraz Önemli, 4- Önemli Değil, 5- Hiç Önemli Değil.

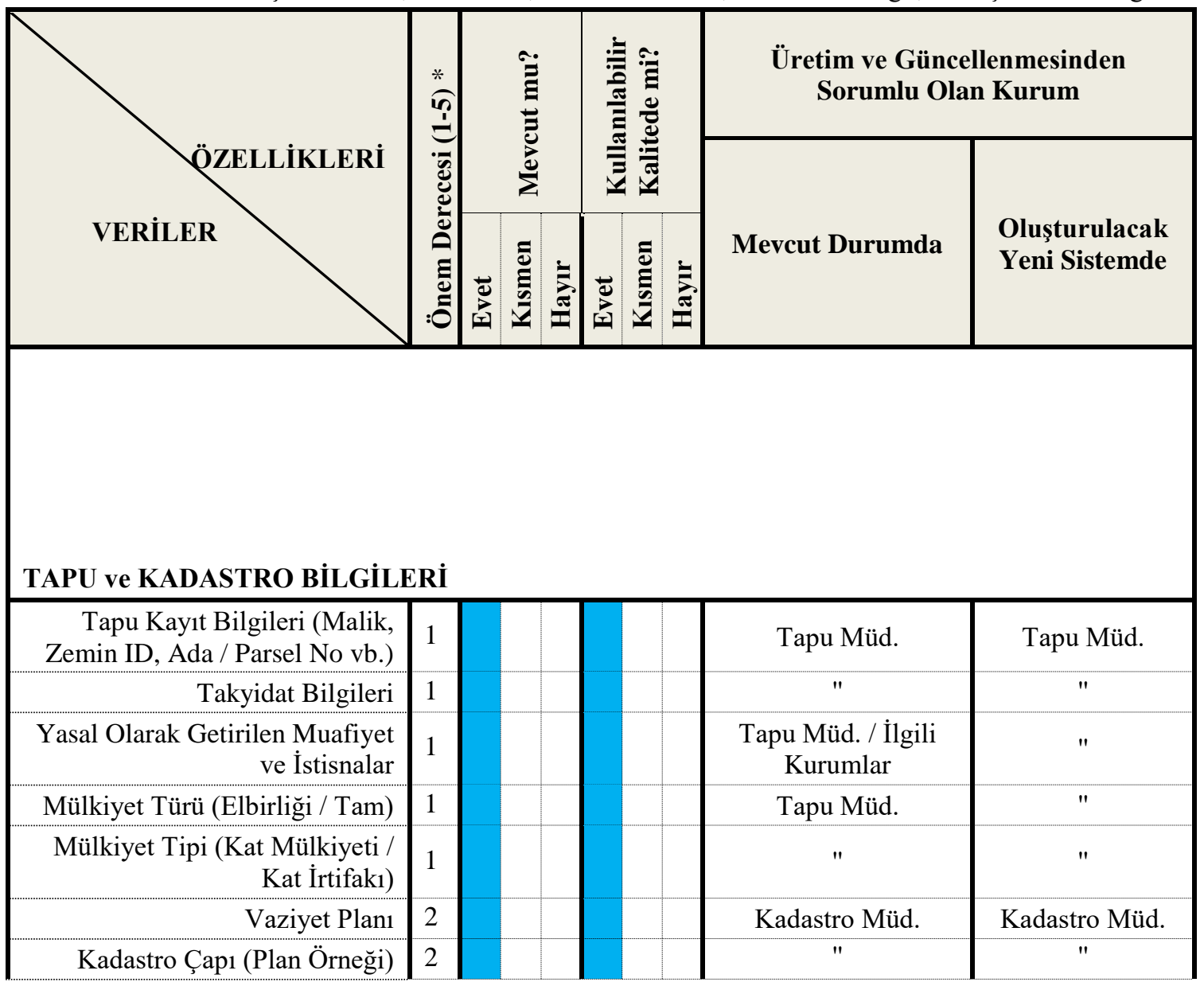




\begin{tabular}{|c|c|c|c|c|c|c|c|c|c|}
\hline \multirow[b]{2}{*}{ VERILLER } & \multirow{2}{*}{ 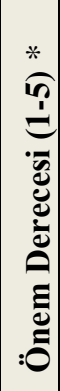 } & \multicolumn{3}{|c|}{ 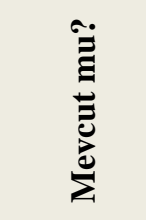 } & \multicolumn{3}{|c|}{ 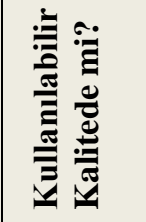 } & \multicolumn{2}{|c|}{$\begin{array}{l}\text { Üretim ve Güncellenmesinden } \\
\text { Sorumlu Olan Kurum }\end{array}$} \\
\hline & & 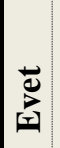 & 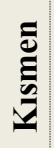 & $\sum_{\bar{\Xi}}^{ \pm}$ & 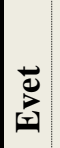 & 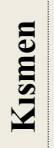 & 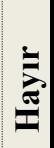 & Mevcut Durumda & $\begin{array}{l}\text { Oluşturulacak } \\
\text { Yeni Sistemde }\end{array}$ \\
\hline Aplikasyon Krokisi & 2 & & & & & & & $"$ & $"$ \\
\hline Emlak Beyan Değeri & 3 & & & & & & & Belediye & Belediye \\
\hline \multicolumn{10}{|l|}{ IMMAR BİLGİLERİ } \\
\hline Anayola Cephesi (Var / Yok) & 1 & & & & & & & Belediye & $"$ \\
\hline İnşaat Alanı & 1 & & & & & & & $"$ & $"$ \\
\hline Emsal & 1 & & & & & & & $"$ & $"$ \\
\hline Nazım İmar Planı & 1 & & & & & & & $"$ & $"$ \\
\hline Uygulama İmar Planı & 1 & & & & & & & $"$ & $"$ \\
\hline Hmax & 1 & & & & & & & $"$ & $"$ \\
\hline Ön Bahçe & 1 & & & & & & & " & $"$ \\
\hline Yan Bahçe & 1 & & & & & & & $"$ & $"$ \\
\hline TAKS & 1 & & & & & & & $"$ & $"$ \\
\hline KAKS & 1 & & & & & & & $"$ & $"$ \\
\hline Yapı Nizamı (Ayrık / Bitişik) & 1 & & & & & & & $"$ & $"$ \\
\hline Plan Notları & 2 & & & & & & & $"$ & $"$ \\
\hline $\begin{array}{r}\text { Parsel Tipi (İmar Parseli, } \\
\text { Kadastro Parseli) }\end{array}$ & 2 & & & & & & & $\begin{array}{c}\text { Kadastro } \\
\text { Müd./Belediye }\end{array}$ & " \\
\hline Arsanın Konumu (Köşe / Ara) & 2 & & & & & & & Kadastro Müd. & $"$ \\
\hline Altyapı İmkanları & 2 & & & & & & & Saha Çalışm./Beld. & $"$ \\
\hline Kullanılmayan İmar Hakkı & 2 & & & & & & & $"$ & $"$ \\
\hline Üzerinde Yapı Olması & 2 & & & & & & & Saha Çalışm./Beld. & $"$ \\
\hline Parsel Büyüklüğü / Geometrisi & 2 & & & & & & & Belediye & $"$ \\
\hline Parsel Derinliği & 2 & & & & & & & $"$ & $"$ \\
\hline Bölgenin Gelişmişlik Durumu & 2 & & & & & & & Saha Çalışması & Saha Çalışması \\
\hline Yapılaşma Yoğunluğu & 2 & & & & & & & Saha Çalışm./Beld. & Belediye \\
\hline
\end{tabular}




\begin{tabular}{|c|c|c|c|c|}
\hline $\begin{array}{l}\text { Kadastro } \\
\text { Müdürlüğüu }\end{array}$ & Belediye & Tapu Müdürlüğü & $\begin{array}{l}\text { Nüfus } \\
\text { Müdürlüğg̈u }\end{array}$ & ÇŞB \\
\hline •Kadastro Verileri & $\begin{array}{l}\text { •İmar Bilgileri } \\
\text { •Adres Bilgileri }\end{array}$ & $\begin{array}{l}\text {-Mülkiyet Verileri } \\
\text { •TAKBIS Verileri }\end{array}$ & $\begin{array}{l}\text {-Malik Bilgileri } \\
\text {-Adres Bilgileri }\end{array}$ & $\begin{array}{l}\text {-Yapı Maliyet } \\
\text { Bedelleri }\end{array}$ \\
\hline Tüik & Merkez Bankası & $\begin{array}{c}\text { KGM, DSi, TCDD, } \\
\text { vb. }\end{array}$ & Mahkemeler & Saha Çalışması \\
\hline $\begin{array}{l}\text { •Ekonomik ve } \\
\text { Demografik } \\
\text { Veriler }\end{array}$ & $\begin{array}{l}\text { •Ekonomik } \\
\text { Veriler } \\
\text { •Döviz\&Altın }\end{array}$ & $\begin{array}{l}\text { - Kamulaştırma } \\
\text { Verileri }\end{array}$ & -Bilirkişi Raporları & $\begin{array}{l}\text { •Taşınmaz Detay } \\
\text { Bilgileri } \\
\text { •Örnek Satışlar }\end{array}$ \\
\hline CBSGM & $\begin{array}{l}\text { Belediye } \\
\text { CSB }\end{array}$ & MEB & TEIAŞ & GSM Şirketleri \\
\hline $\begin{array}{l}\text {-Altyapı Verileri } \\
\text {-Veri Standartları }\end{array}$ & $\begin{array}{l}\text { •Çevre ve } \\
\text { Konum } \\
\text { Özellikleri }\end{array}$ & $\begin{array}{l}\text {-Aktif ve } \\
\text { Planlanan } \\
\text { Eğitim Alanları }\end{array}$ & $\begin{array}{c}\text {-Trafo ve Enerji } \\
\text { Nakil Hatları }\end{array}$ & $\begin{array}{l}\text {-Baz } \\
\text { İstasyonları }\end{array}$ \\
\hline DPT & Tarım îl Müd. & Kültür ve Turizm & Meslek Odaları & Özel Sektör \\
\hline $\begin{array}{l}\text {-Kalkınma } \\
\text { Planları } \\
\text {-Projeler }\end{array}$ & $\begin{array}{l}\text { •ÇKS ve TÜKAS } \\
\text { Verileri } \\
\text { •Toprak Niteliği } \\
\text {-Sulama Şekli }\end{array}$ & $\begin{array}{l}\text {-Turistik Tesisler } \\
\text { •Tarihi Eserler } \\
\text { •Koruma Alanları }\end{array}$ & $\begin{array}{l}\text { •Taşınmaz, } \\
\text { Yetiştirilen } \\
\text { Ürün ve Çevre } \\
\text { Bilgileri }\end{array}$ & $\begin{array}{l}\text {-Değerleme } \\
\text { Raporları }\end{array}$ \\
\hline
\end{tabular}

Güncel + Güvenilir + Anlaşılabilir + Kullanılabilir + Erişilebilir + Tam + Kapsaml + Standartlara Uygun

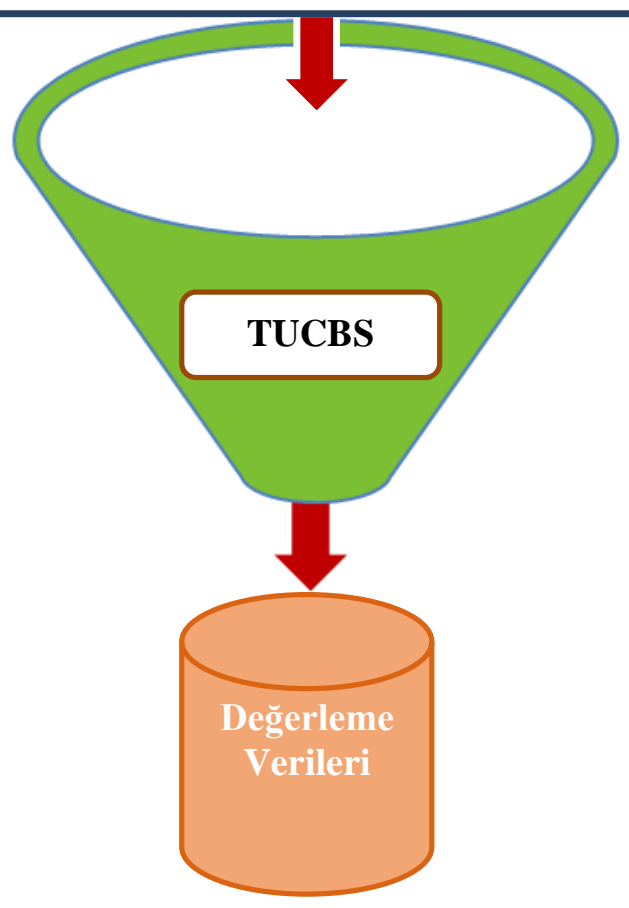

Şekil 3. Taşınmaz Değerleme Veri Kaynakları ve Alınması Gereken Veriler. 
TADES yaklaşımının teknik anlamda önemli özelliği, taşınmaz karakteristikleri ve emsal satışlar veritabanının etkin bir şekilde tesis edilmesi ve sürdürülmesinin altyapısını oluşturmasıdır. $\mathrm{Bu}$ bağlamda, yaklaşım içerisinde önerilen Taşınmaz Değerlemesi Genel Müdürlüğü (TDGM)'nin, kurumsal anlamda en temel özelliği; değerleme faaliyetlerini düzenleyen, yol gösteren ve denetleyen olmasıdır (Şekil 4).

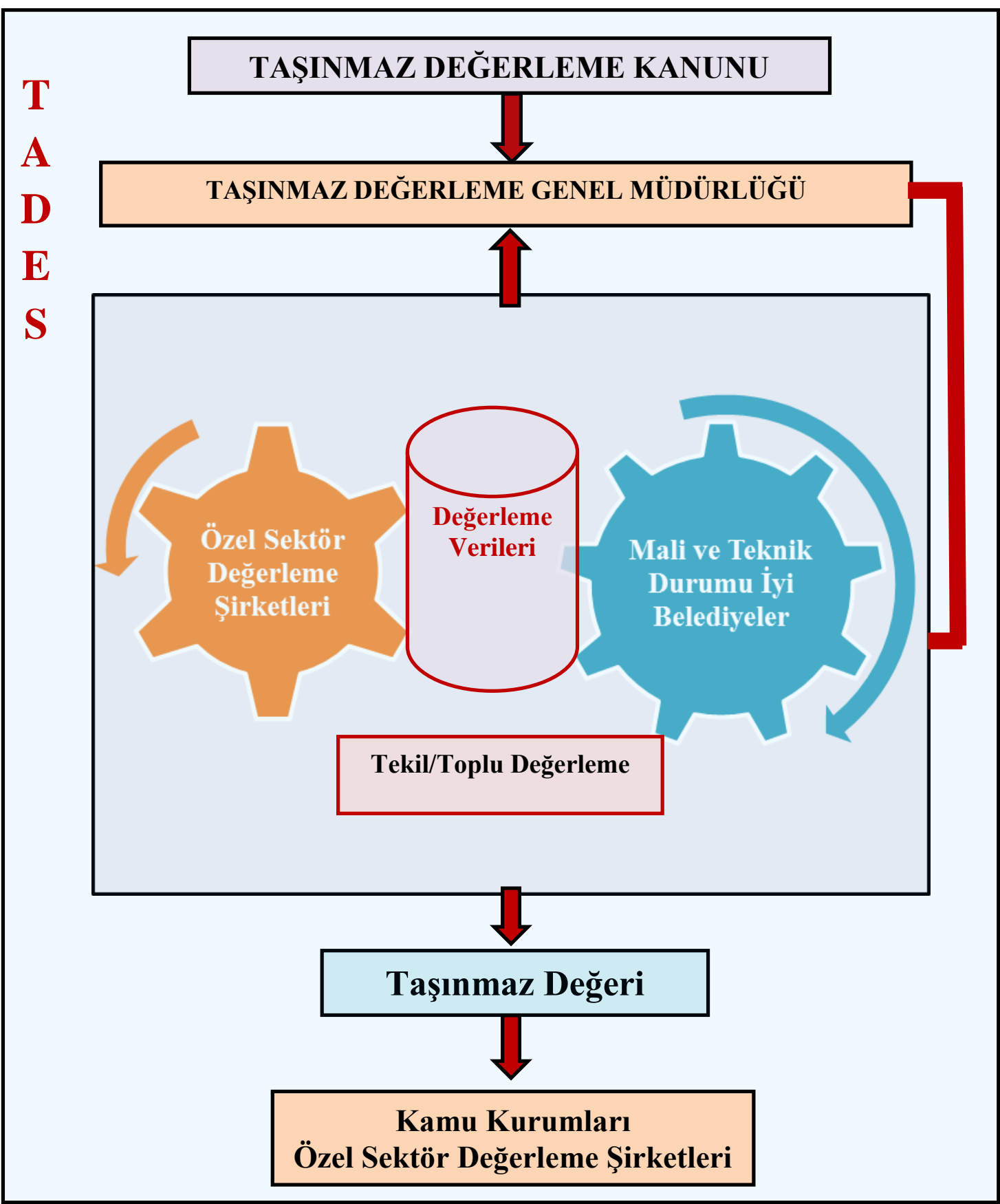

Şekil 4. Türkiye Taşınmaz Değerleme Sistemi (TADES)'in Temel Mekanizması. 
Taşınmaz değerlemesinde büyük öneme sahip olan mülkiyet bilgilerinin, doğru ve güncel olarak üretilmesi gerekmektedir. TKGM, bu görevin bilinciyle, uzun y1llara dayanan araştırma sonuçlarını değerlendirmiş ve sahip olduğu deneyime binaen TAKBİS projesinin hayata geçirilmesine karar vermiştir. Vergi kaybının önlenmesi ve taşınmaz mallar ile ilgili işlemlerin gerçek değerleri üzerinden yürütülmesi için, taşınmaz malların gerçek değerlerini belirleyecek mülkiyet, değerleme ve taşınmaza dayalı sigorta sistemi (deprem, yangın, sel, toprak kayması, hileli satış) için TAKBİS önemli bir altlık olacaktır (TDUB, 2011). Bu bağlamda TAKBİS'in ülke geneline yaygınlaştırılması durumunda, önerilen TADES modelinde gerekli olan güncel ve doğru mülkiyet bilgilerinin erişilmesinde, TAKBIS verilerinden yararlanılacaktır. Sonuçta bu temel bilgilerin kullanılmasıla, veri toplama tekrarına düşülmeden, kurumlar arasında çevrimiçi servisler aracılığı ile bilgi paylaşımı gerçekleștirilmiş olacaktır. Ancak, değerleme veri bileşenlerini üreten ve güncelleyen kurumların da tüm çalışmalarını TUCBS ve TUGDES standartlarına uyumlu bir yapida yürütmeleri gerekecektir.

\section{Tapu Kayıtlarının Güncelliği}

Türk Medeni Kanunu ile TKGM Teşkilat ve Görevleri Hakkında Kanun hükümleri uyarınca tapu sicillerinin düzenli ve güncel tutulmas1 TKGM'nin asli görevlerinden birisidir. Ancak, çalışma kapsamında yapılan mülakatlar sırasında, ülkemizde taşınmaz değerlemesiyle ilgili faaliyet yürüten kurumların çalışan ve idarecileri ile özel sektör değerlemecileri tarafindan sıklıkla ifade edilen sorunların başında, değerlemenin en önemli girdi verilerinden biri olan tapu kayıtlarının güncel olmaması sorunu gelmektedir. Örneğin taşınmaz sahibinin vefatından sonra yapılması gereken "veraset intikal" işlemleri ile taşınmaz nitelik değişikliklerinde yapılması gereken "cins değişikliği” işlemlerinin yapılmamış olması, başta kamulaştırma projelerindeki değerleme faaliyetleri olmak üzere birçok uygulamada büyük sıkıntılara yol açmaktadır.
Mevzuatımızda bu işlemlerle ilgili bir süre sinırlamasinın bulunmaması, durumun daha karmaşık hale gelmesine neden olmaktadır (Çete, 2008).

Vefat eden ve tapuda kayıtlı taşınmazı bulunan kişilerin mirasçıları aradan on yıllar geçmesine rağmen mahkemeden mirasçılık belgesi alıp tapuda mirasçılar adına intikalleri yaptırmamaktadırlar. Mirasçıların veraset intikal işlemlerini yaptırmamalarının, ihmalkârlık, intikal işlemlerindeki bürokrasinin çokluğu inancı, mirasçıların veraset ve intikal vergisi ödemek istememeleri, 1992 yılından beri uygulanan, Yeşil Kartlılar ile Genel Sağlık Sigortasına ve gelir testine tabii vatandaşın tapuda intikal yaptırmayarak üzerinde taşınmaz mal görülmesini istememesi gibi birçok nedenleri bulunmaktadır (Y1lmaz, 2012).

Ülkemizde tapu uygulamalarında otomatik intikal de diyebileceğimiz bir dönem başlatılmak istenmiştir. Nitekim bu konuda kurumların elini güçlendirmek adına, 18 May1s 2012 tarihli Resmi Gazete'de yayınlanan 03.05.2012 tarih 6302 sayılı Tapu Kanunu ve Kadastro Kanununda Değişiklik Yapılmasına İlişkin Kanun'un 3. maddesiyle 2644 say1l Tapu Kanununa "Ek Madde-1" eklenmiştir. İlgili madde gereğince, bundan böyle ölüm halinde miras bırakanın adına kayıtlı taşınmazın iki yıl içerisinde mirasçıları tarafından tapuda intikali yapılıp kendi adlarına kayı yaptırmamaları durumunda ilgili Tapu Müdürlükleri yetkili Sulh Hukuk Mahkemesinden mirasçılık belgesi alıp, mirasçılar adına tescil işlemi yapabilecektir (Y1lmaz, 2012). Ancak, Tapu Müdürlüklerinde yapılan araştırmalara göre; söz konusu maddenin uygulanmasıyla ilgili herhangi bir yönetmelik veya genelge yayınlanmadığından, Tapu Müdürlüklerince bugüne kadar bu konuda hiç bir işlem yapılmadığı görülmüştür. Dolayısıyla tapu kayıtlarındaki güncellik sorunu hala devam etmektedir. Esasen murislerin, böyle bir işleme gerek kalmadan, intikallerini zamanında yaptırmaları, hem ödemek zorunda kalacakları bazı mahkeme masraflarından kurtulmalarını sağlayacak, hem de zaten çok 
yoğun olan adliyelerin yükünü bir nebze olsun azaltılmasında katkısı olacaktır.

Çete 2008'e göre; veraset intikal işlemleri sorununun çözüme kavuşturulabilmesi için, ülkemizde de, Almanya'dakine benzer bir teşvik sisteminin geliştirilmesine ihtiyaç vardır. Almanya'da, murisin vefatını takip eden iki yıllık süre zarfında intikal işleminin yapılmas1 durumunda, varislerden herhangi bir ücret alınmamakta, bu sürenin dolmasından sonra yapılacak intikal ișlemleri ise harca tabi tutulmaktadır. Ülkemizde de böyle bir sistemin uygulanması, tapu kayıtlarının güncelliği ile ilgili sorunların çözümünde önemli katkıları olacaktır.

\section{Tapu ve Kadastro Verilerine Erişim}

Değerleme sektöründe yaşanan en önemli sorunlardan biri, veri temininin hizlı ve çerçevesi belli bir mevzuata bağlı olmamasıdır. Değerlemede ihtiyaç duyulan verilerin tamamına yakını kamu kurum ve kuruluşlarında bulunmaktadır. Ancak, bu bilgi ve belgelere ulaşmakta ciddi sıkıntılar yaşanmaktadır. Örneğin bir kişi bir tapu veya kadastro müdürlüğünde veriye kolaylıkla ulaşabilirken, bir başkası aynı müdürlükte aynı veriye ulaşmayabilmektedir. Ocak 2013 itibariyle, mevzuatta yapılan bir tak1m değişiklikler çerçevesinde, değerleme uzmanlarının tapu veya kadastro müdürlüklerinden veri temininde bazı düzenlemeler getirilmiş olsa da, TAKBİS'ten olmas1 gerektiği ölçüde faydalanılmamaktadır. Harç yatırma, tapu kayd1 inceleme gibi işlemler çevrimiçi (online) sistemlere bağlanmaya çalışılıyor olsa dahi, ilgili kurumların isteksizliği, teknolojiyi yakından takip etmemeleri ve çalışanların duyarsızlığından dolayı zaman içerisinde işlemler daha da zorlaşmakta ve yavaşlamaktadır.

22.11.2001 tarih ve 4721 sayıl1 Türk Medeni Kanunu'nun 1020. maddesinde; “Tapu sicili herkese açıktır. İlgisini inanılır kılan herkes, tapu kütüğündeki ilgili sayfanın ve belgelerin tapu memuru önünde kendisine gösterilmesini veya bunların örneklerinin verilmesini isteyebilir." hükmü yer almaktadır. Buna göre mevzuatımızda mülkiyet verilerine erişim, ilginin inanılır kılınması ile sınırlandırılmıştır (Çete, 2008). Özel sektör değerleme uzmanlarının da ilgili kanunun bu hükmü gereği tapu kütüğünü incelemede yetkilendirilmesi şartıyla herhangi bir sorun yaşamaması gerekmektedir. Çalıştıkları şirketlerden alacakları yetki belgelerini kullanarak istedikleri tapu verilerine ulaşabilmelidirler. $\mathrm{Bu}$ konuda yaşanan sorunun İsviçre modeli ile çözümü mümkündür. Nitekim İsviçre'de de bir sorun olarak görülen bu hüküm, 2004 yılında değiştirilerek erişim hakları genişletilmiştir (Rissi, 2013).

Çete 2008'e göre; ülkemizde de kişisel gizlilik haklarını göz ardı etmeden benzer bir değişikliğin hayata geçirilmesine ihtiyaç vardır. $\mathrm{Bu}$ bağlamda Türk Medeni Kanunu'nun 1020. maddesi yeniden düzenlenerek; herhangi bir taşınmaza ait temel bilgilere (malik, yüzölçümü, üzerinde kısıtlama olup olmadığ 1 vb.) erişime olanak sağlanmalı, ancak, isim tabanlı sorgulamalar yapmak veya taşınmaz üzerindeki ipotek kredisi bilgilerine ulaşmak gibi gizlilik haklarına müdahale sayılabilecek yaklaşımlar üzerindeki kısıtlamalar devam ettirilmelidir.

\section{Mekânsal Gayrimenkul Sistemi (MEGSíS)}

Mekânsal Gayrimenkul Sistemi (MEGSIS); sayısal olarak kadastro müdürlüklerinin yerel bilgisayarlarında yer alan CAD tabanlı verilerin merkezi bir sistem üzerinde toplanarak tapu bilgileri ile eşleştirilmesi ve bu bilgilere ihtiyaç duyan paydaş kurum, kuruluş ve belediyeler ile uluslararası standartlarda harita servisleri aracılığıyla paylaşılması, e-Devlet kapısı üzerinden vatandaşlara sunulması amaciyla TKGM tarafından projelendirilerek hazırlanmış açık kaynaklı bir uygulamadır. MEGSIS uygulamasındaki "parsel sorgulama" linki ile istenilen parsel hakkında bilgiye ulaşılabilmektedir (URL_1). 
MEGSIS'in web tabanlı uygulama yazılımı, uygulamanın farklı düzeylerde ve ihtiyaçlarda kullanımını sağlayan ve yöneten kimliklendirme/yetkilendirme çatısı altında, iç ve dış kullanıcıların sisteme veri girişi, veri indirme, tapu verileri ile entegrasyon işlemleri ve sorgulamaları, yapılan işlerin kontrol ve takibini içeren modüllerden oluşmaktadır. MEGSIS ile yaklaşı 52 milyon kadastro parselinin sisteme yüklenmesi sağlanmıştır. Veri girişleri yapılan kadastro bilgilerinden yaklaşık 50 milyon parselin tapu verileri ile uyumlaştırılması yapılmış ve kadastro müdürlükleri tarafından iyileştirme, güncelleme ve kesinleştirme çalışmaları sürdürülmektedir. $\mathrm{Bu}$ çalışma ile TKGM tarafindan ulusal düzeyde üretilen mekansal verilerin merkezi bir yapıda ilişkisel olarak tutulması ve bu bilgilerin mekana bağlı tüm arazi bilgi sistemleri için sunulmasının teknik ve ekonomik birçok yararı olacaktır. Ayrıca, INSPIRE (Infrastructure for Spatial Information in the European Community) ve TUCBS (Türkiye Ulusal Coğrafi Bilgi Sistemi) tarafından tanımlanan kadastro veri setinin bir an önce oluşturulması başta önerilen TADES yaklaşımı gibi uygulamalar olmak üzere tüm çalışmalara hız katacaktır (URL_1).

\section{Kamusal Hak ve Kisitlamalar Kaydı}

4721 sayılı Türk Medeni Kanunu'nun 780. maddesinde, "İrtifak hakkının kurulması için tapu kütüğüne tescil şarttır." hükmü yer almaktadır. Bu bağlamda, ülkemizde hak ve sinırlılıklar tapu siciline idari irtifak hakları şeklinde kaydedilmekte ve kadastro paftasında gösterilmektedir. Ancak, askeri yasak bölgeler, sit alanları, kıyı kenar çizgileri, fiziki planlar gibi kamusal hak, k1sitlama ve sorumluluklar mülkiyet haritalarında yer almamaktadır (Çete, 2008; Başer, 2014). Uluslararası Haritacılar Federasyonu (FIG) tarafindan 1998 yilında yayınlanan Kadastro 2014 raporu, geleceğin kadastrosu ile ilgili öngörüleri içeren önemli bir vizyon çalışmasıdır. Bu rapora göre 2014 Kadastrosu; kamusal hak ve kisitlamalar da dahil olmak üzere arazi üzerindeki tüm yasal durumu göstermelidir. Kadastro 2014'ün yayınlandığ 1 yıl olan 1998 'den bugüne ülkemizde bu vizyon raporunda yer alan ifadeler kapsamında TKMP ve bileşenleri, ülke kadastrosunun bitirilmesi, 22/A uygulamaları ve sayısal kadastro çalışmaları gibi bir takım gelişmelerin yaşandı̆̆ görülmektedir. Ancak, bu gelişmelerin daha da ileriye taşınmasına ihtiyaç vardır (Çete, 2014).

Kamu hukuku kısitlamalarının kadastroda kaydedilmesi konusunda İsviçre'de 2012 yılında bir pilot proje başlatılmış ve 8 Kanton projeye dâhil edilmiştir. 2015 yılında tamamlanması planlanan pilot projede, başlangıçta arazi mülkiyetini kısıtlama potansiyeline sahip 150 muhtemel kamu hukuku kısıtlaması tanımlanmış, ancak, teknik ve politik açıdan fizibilite sağlamak amacıyla bu rakam 17'ye indirilmiştir. Kamu hukuku kısıtlamaları kadastrosu, teknik ve kavramsal olarak geleneksel kadastro ile aynı prensiplere sahiptir. Ülkede 17 kısıtlamanın tamamı için kabul edilmiş ve tanımlanmış birer veri modeli mevcut olup, her bir kısıtlama, iş akışı ve sorumlulukların açı bir şekilde tanımlanmasına imkân tanıyan ayrı bir veri katmanında tutulmaktadır (Şekil 5), (Çete, 2014).

Arazi üzerindeki bütün kamusal hak ve kısıtlamaların kadastroda gösterilmesi, taşınmaz değerleme çalışmalarında da önem arz etmektedir. Bu nedenle ülkemizde de bu alanda bir an önce çalışmalara başlanması gerekmektedir. 


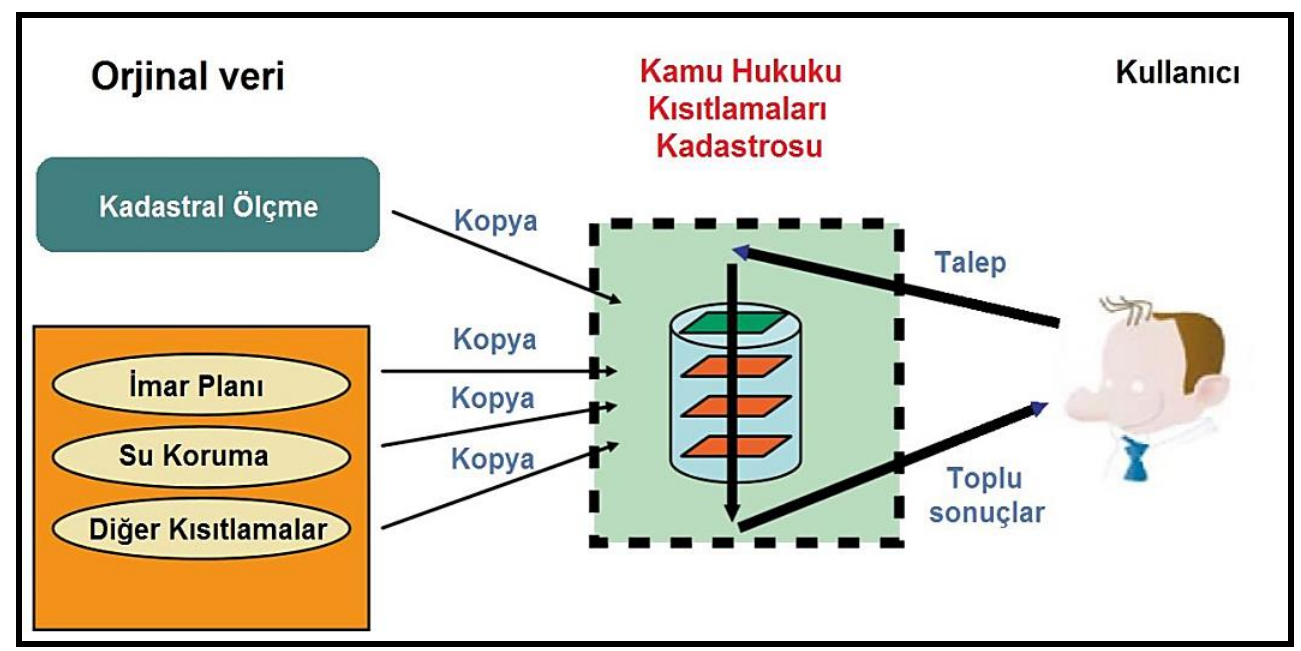

Şekil 5. İsviçre'deki Kamu Hukuku Kısıtlamaları Kadastrosunun İşleyişi (Çete, 2014).

\section{Belediye Kayıtlarının Güncelliği ve Erişim}

Diğer birçok kurumda olduğu gibi belediyelerde de değerleme mesleğinin esası olan dikkatli ve yoğun bir çalışma yapılması gerekmektedir. Ancak, ilgili kurumlarda (başta belediyeler olmak üzere) araştırma izni verilmesi konusunda çeşitli zorluklar yaşanmaktadır. Bir diğer sorun da, arşiv sistemlerinin iyi kurulmamış olmasından dolayı büyük zorluklarla ulaşılabilen bilgilerin ya eksik ya da hatalı olabilmesidir.

Bu bağlamda, çalışma kapsamında, değerleme uzmanlarıyla yapılan mülakatlar sırasında, belediyelerden veri temini, alınan verilerin kalitesi ve güncelliği ile ilgili sorunlar yaşanmakta olduğu ifade edilmiştir. Özellikle kat irtifak1 ve kat mülkiyetine konu taşınmazlarda bağımsız bölümlerin yüzölçümlerinin kayıt altına alınmaması nedeniyle bu alanda bir veritabanı oluşturulamadığı gibi, bağımsız bölüm satın alan vatandaşlar, müteahhit veya emlakçılarca yanlış bilgilendirilmesinden dolayı mağduriyet yaşayabilmektedirler. $\mathrm{Bu}$ mağduriyet, Kat Mülkiyeti Kanunu'na göre bağımsız bölümlerin yüzölçümlerinin mimari projede gösterilmesi zorunlu olduğundan, mevzuat değișikliğine gerek duyulmaksızın, belediyelerce onaylı mimari projedeki listede bağımsız bölümlerin yüzölçümlerinin gösterilmesi ve TAKBİS'de bu konuda yapılacak bir düzenleme ile giderilmesi gerekir. Ancak bu durumla ilgili sorunlar henüz çözülmüş değildir.

Belediye kayıtlarının güncelliği ve erişimiyle ilgili yaşanan bir diğer sorun da, emlak vergisine matrah olacak taşınmaz değerlerinin (rayiç değer) doğru ve hızlı bir şekilde belirlenmiyor olmasıdır. Eğer bu, önerilen lider kurum TDGM kontrolündeki toplu değerleme uygulamalarıyla gerçekleştirilebilirse, hem emlak beyan değerine dayalı olarak tapu sicil müdürlüklerindeki devir işlemlerinden alınan vergi oranları artacak, hem de özel sektör değerleme uzmanlarının hazırladıkları raporların dayandıkları veriler daha sağlıklı hale gelecektir.

Belediyelerden veri teminini kolaylaştıracak uygulamalardan biri de Kent Bilgi Sistemlerinin kurulmasıdır. Böylece belediye kayıtlarına erişim konusunda çevrimiçi çalışacak sistemler geliştirilebilir. Başta özel sektör değerleme uzmanları/kuruluşları olmak üzere yetkilendirilmiş diğer kullanıcılar da, yapacakları tekil/toplu değerleme çalışmaları için gerekli olan verileri bu sistemden belli bir ücretlendirme veya yapilacak protokoller gereği temin edebilirler. Çalışma ofislerinden istedikleri belediye kayıtlarına (imar durumu, yap1 tatil tutanakları, encümen kararlar1, yap1 ruhsat1, yap1 kullanma izin belgesi ve proje gibi) internet ortamından ulaşabilirler. Dolayısıyla yoğun, yorucu ve çok zaman alan 
saha çalışmaları hızlandırılabilir. Ancak, burada belediyelere önemli görevler düşmektedir. Öncelikle sistemin sürdürülebilirliği için, bu konuda kararlı ve istekli (veya kanunen/yönetmelikle zorunlu) olmaları, devamlı olarak veri güncellemeleri yapmaları ve yetişmiş teknik personeli istihdam etmeleri gerekmektedir.

\section{TKGM TARAFINDAN YAPILAN TAŞINMAZ DEĞERLEME TEMEL VERİ YÖNETIMMI}

TKGM Detaylı Pilot Eylem Planı Raporu (2014)'e göre;

Gayrimenkullerin devir işlemleri sırasında, gerçekleşen satış fiyatları hususunda doğru beyanda bulunulmaması ve "değer" bilgilerinin ortak bir veritabanı içerisinde tutulmamas1 veri kaynağ1 konusundaki problemlerin başında gelmektedir. Pilot uygulama alanlarında seçilen taşınmazlarda, bağımsız değişkenlere ilişkin veriler, temel olarak; TAKBİS, Tapu Müdürlüğü ve Belediyeler ile sahadan temin edilmiştir.

Taşınmaz değerlemenin doğru ve pazar değerine en yakın biçimde oluşturulabilmesi, büyük ölçüde kadastro verilerinin doğruluğuna, güncelliğine ve değerleme için gereken bilgilerin gereken özellik ve incelikte değerleme uzmanına sunulmasına bağlıdır. Değer bilgileri belirli bir düzen içinde ya da gerektiğinde güncellenmelidir. Özellikle; plan değişikliği olduğunda, kullanım değişikliği yapıldığında, her 4 ya da 5 yılda bir yeniden değerleme yapılmalıdır. Kadastro verilerine ulaşma ve edinme ise:

- Gizli olacak verilerin yasa ile belirlenmeli (kişisel-mülkiyet hakkına vb. ilişkin bilgiler),

- Gizli bilgiler dişındaki bilgilerin herkesin ulaşımına ya da özellikle değerleme uzmanlarının, değerleme kuruluşlarının ulaşımına ve kurum ve kişilere açik, ulaşılabilir, edinilebilir olması mevzuatta yer almalıdır.

- İşbirliği ve veri akışı standartlarını oluşturma ve izleme görevi, TKGM'nin zorunlu görevi olmalıdır. Taşınmaz mal değerlerinin güncel, doğru belirlenebilmesi ve sürekli izlenebilmesi için, kurumlar arasında sağlıklı bir veri akışı kurulmalıdır.

- Değerleme çalışmalarının ekonomik gerçekleştirilebilmesi ve malik ilgisini sağlanabilmesi için maliklerin değer beyanı ve yöntemleri mevzuatta yerini almalıdir.

\section{TKMP'de Veri Toplamada Yaşanan Sorunların Çözümü İçin Öneriler}

TKGM Detaylı Pilot Eylem Planı Raporu (2014)'e göre;

Değerleme çalışmalarının ana unsurlarından olan ve ilgili belediyelerden temin edilmesi gereken, taşınmazların belgeler ile belediye hizmetlerinden yararlanma, belediye imar ve mücavir alanı sınırları ile ilgili altlıkların teknolojiden de yararlanılarak dijital ortama aktarılması ve internet üzerinden değerleme uzmanlarının kullanımına sunulması için gereken teknik ve yasal altyapı çalışmalarının tamamlanması gerekmektedir.

Veri aktarımının gecikmesi ihtimaline karşı değerleme uzman ve uzman adayı olarak çalışan kişilerin belediyelerde bu belgeleri inceleyebilmelerine yönelik uygulama birliği sağlanmalıdır.

TAKBİS bilgilerinin, değerlemenin taraflarına açılması için gereken teknik ve yasal altyapı çalışmaları yapılmalıdır.

Tapu ve Kadastro Müdürlüklerinde tutulan taşınmaz kayıtlarında (TAKBİS) gerekli düzenlemeler yapılmalı ve tapu senetleri üzerindeki bilgiler görülecek şekilde değişiklikler, yenilemeler/düzeltmeler yapılabilmelidir. Rasyonel değerleme için gerekli düzenlemelerin yapılabilmesi için gerekli bilgi temini ve yasal altyap1 oluşturulması zorunludur.

- Adrese dayalı kayıt sistemi verileri, tapu ile uyumlu hale getirilmeli ve kullanıma sunulmalidir.

- Kadastro çalışmaları taşınmazın fiziki ve geometrik özelliklerinin yanı sıra taşınmazın niteliklerini ve değerine etki edebilecek unsurları da içermelidir. 
- Değerleme çalışmaları sırasında, taşınmazın durumuna göre bilgi ve belge alınması gereken diğer kamu kurumlarında da, gerekli bilgi ve belgelerin veri tabanına aktarılması suretiyle değerlemenin taraflarının kullanımına açılması için gerekli teknik, idari ve yasal altyapı çalışmalarının yapılması gerekmektedir.

- Yapılacak çalışma hem kayıtların güncel ortamda tutulmasını sağlayacak, hem de bilgi belge ve evrakların kaybolmasını veya kötü niyetle ortadan kaldırılmasını engelleyecektir.

- Değerleme çalışmaları bu sayede daha hızlı yapılabileceğinden ekonomik olarak kaynak israfinın da önüne geçilmiş olacaktır.

\section{UML TABANLI VERI MODELI TASARIMI}

"Unified Modeling Language" İngilizce ifadesinin kısaltması olan UML, nesne yönelimli tasarım çalışmaları için grafik gösterimler sunmakta ve yaygın bir şekilde kullanılmaktadır. $\mathrm{Bu}$ gösterimler, ilgili çalışmanın farklı yönlerini temsil eden farklı diyagramlar olabilmektedir (Page-Jones, 2002; İnan, 2010). Tümleşik (Bütünleşik) Modelleme Dili olarak da bilinen UML, sistem bileşenlerinin belirlenmesinde, görselleştirilmesinde ve belgelenmesinde kullanılan genel amaçlı görsel bir modelleme dilidir. UML günümüzde, yazılım mühendisliği, iş süreçleri için iş akışları ve konumsal veri modelleme gibi çeşitli alanlarda en s1k kullanılan nesneye yönelik kavramsal bir modelleme dili olmuştur. Nesne Yönetim Grubu (Object Management Group) denetiminde bir endüstri standardına dönüşmüştür (Çağdaş, 2007; İnan, 2010).

Ülkemiz taşınmaz değerleme sisteminin yeniden yapılandırılması için önerilen TADES yaklaşımında, taşınmaz değerlemeye altlık oluşturacak taşınmaz karakteristikleri ve emsal satışlar veritabanlarının oluşturulması, bunun için kullanılacak verilerin temini, kalitesi ve güncelliği konusunda uzmanlarla yapılan görüşmelerden sonra, UML tabanlı bir veri modeli tasarımı oluşturulmuştur. Model tasarımında verilerin kendi yapı özelliklerine uygun şekilde modellenmesini sağlayan nesne yönelimli yaklaşım kullanılmıştır. Model bir veri ihtiyaç analizi şeklinde yorumlanarak oluşturulmuştur. Değerleme alanındaki uluslararası standartlara dayalı ulusal bir uygulama standartlarının belirlenmesi ve geliştirilmesine, değerleme veri kaynaklarının yapılandırılması ve bütünleşik olarak kullanılmasına da önemli katkılar sağlayacağı düşünülmektedir (Bostanc1 vd., 2012).

Değerleme verilerinin toplanmas1 ve bir veritabanı kurulumundan sonra, tekil ve toplu değerlemelerle ilgili TADES yaklaşımında önerilen sistemin hayata geçirilebilmesi ve sürdürülebilirliğinin sağlanması gerekir. Bunun için, veri analiz yöntemleri ve veri üreten kurumlar arasındaki paylaşım sırasında uyulması gereken bir takım idari ve işbirliği kurallarını içeren bir dizi yönetmeliğin çıkarılmasına da ihtiyaç vardır.

Modelde tanımlanan değerleme verilerinin zamanla değişebileceği gerçeğinden hareketle, alacakları farklı değerler ölçeklenebilir/karşılaştırılabilir olmalıdır. Bu şekilde oluşturulacak bir değerleme veri modeli, özellikle ülkemiz için çok büyük gereklilik olan toplu değerleme yönteminin uygulanmasında önemli bir altlık oluşturacaktır. $\mathrm{Bu}$ amaçla, değerlemede kullanılması gereken ve özellikle sayısal olmayan verilerin standardizasyonu için ivedilikle çalışılmalar yapılmalıdır (Bostancı vd., 2012).

UML diyagramlarıyla gösterimde, daha önce yapılan anket çalışmasında önemli görülen veriler, sınıflar içerisinde öznitelik verileri olarak kullanılmıştır. Çünkü UML'e göre ortak özelliklere sahip nesnelerin temsili için sinıfar kullanılması gerekmektedir (Bostanc1 vd., 2012). Farkl1 gruplara/paketlere ait verileri temsil eden sinıflar sirasıyla; Sahadan Alınan Veriler, Tapu Kadastro Bilgileri, Ekonomik ve Demografik Özellikler, İmar Bilgileri, Taşınmaz Türleri, Emsal Satışlar, Çevre ve Konum Özellikleri veri setlerinde yer alan sinıflar farklı renklerle gösterilmiştir. Ayrıca bütün bu verileri kullanarak elde edilecek taşınmaz değerleri için, gerçek veya tüzel kişilerce tekil/toplu değerlemelerde izlenmesi gereken işlem adımlarının 
belirlendiği TaşınmazDeğerlemesi paketi de oluşturulmuştur (Şekil 6).

Paketlerde yer alan veriler siniflarla temsil edilmiştir. Konumsal verilerin geometrileri ISO 19107 (2003) uluslararas1 standardından esinlenerek GM_Point, GM_LineString, GM_Polygon ve GM_Raster olarak tanımlanmıştır. Bütün özniteliklerin veri tipleri tanımlanmış ve ayrıca sınıflanması öngörülen veri tipi tanım kümeleri, detay/özellik tipi ve kod listeleri (Enumeration, FeatureType ve CodeList) belirlenmiştir (Bostanc1 vd., 2012). Veri gruplarında yer alan siniflar arasinda öngörülen ilişkiler bağımlılık/kullanım, ilişkili olma, genelleme/özelleme (dependancy/use, association, generalization /specialization) gibi uygun ilişki türleriyle gösterilmiştir. Bağımlılık/kullanım (Dependency/use) ilişkisi sınıflar arasındaki dinamik ilişkiler için, diğer ilişkiler ise sınıflar arasındaki statik (mantıksal) ilişkileri tanımlamak için kullanılmıştır (Bostancı vd., 2012).

Değerleme alanında gelişmiş ülkelerde olduğu gibi, kullanılması gereken verilerin elektronik ortamdan erişilebilmesini sağlayan veri tabanları oluşturulmalıdır. Uzmanlar, üyelik ve belli bir ücret karşllığında bu verilere ulaşabilmelidir. Böylece rapor hazırlama sürecinde yaşanabilecek gecikme ve hatalar en az seviyeye indirilebilecektir. Modelde bu önerilen veritabanının statik yapısının ortaya konulabilmesi için UML veri modeli paket içerikleri bu esasa göre oluşturulmaya çalışılmıştır (Şekil 6). Sahadan Alınan Veriler paketinde Rayiç Değeri sınıfi oluşturulmuştur. Rayiç değerin oluşumunda önemli faktörlerden olan emsal alım-satım değerleri için; taşınmazın bulunduğu bölgedeki kamulaştırma değerleri, özelleştime ve kira değerleri gibi verileri kapsayan Emsal Satışlar paketi tasarlanmıştır. $\mathrm{Bu}$ ve benzeri ilişkilerden dolayı paketler arasında $<<$ use $>>$ ilişkisi kurulmuştur (Şekil 6).

TaşınmazDeğerlemesi paketi, işlem adımları sırasında kullanım zorunluluğu olan diğer paketlerle ilişkisi $<<$ use $>>$ ile tanımlanmıştır. Değerleme işleminin gerçekleşmesi için taşınmazın sahip olduğu özelliklerin bindirme analizleri uygulanarak TaşınmazDeğerlemesi veri paketiyle ilişkilendirilmesi gerekmektedir. $\mathrm{Bu}$ işlem konumsal analiz sonucu elde edileceğinden modeldeki değerlemede kullanılacak veri paketleri TaşınmazDeğerlemesi veri paketiyle dinamik bir iliş̧ki olan <<use >> ilişkisi ile temsil edilmiștir (Bostancı vd., 2012).

Veri içeriği açısından en önemli ve karmaşık veri setidir. $\mathrm{Bu}$ veri setine ait sinıflar sarı renkte gösterilmiştir (Şekil 6). Diğer veri setleri içeriğinde yer alan ve farklı renkte görülen sınıflar, Taşınmaz Değerlemesi veri seti içeriğindeki sınıflarla ilişkilerinin gösterilebilmesi amacıyla grafikte yer almıştır (Bostanc1 vd., 2012). 


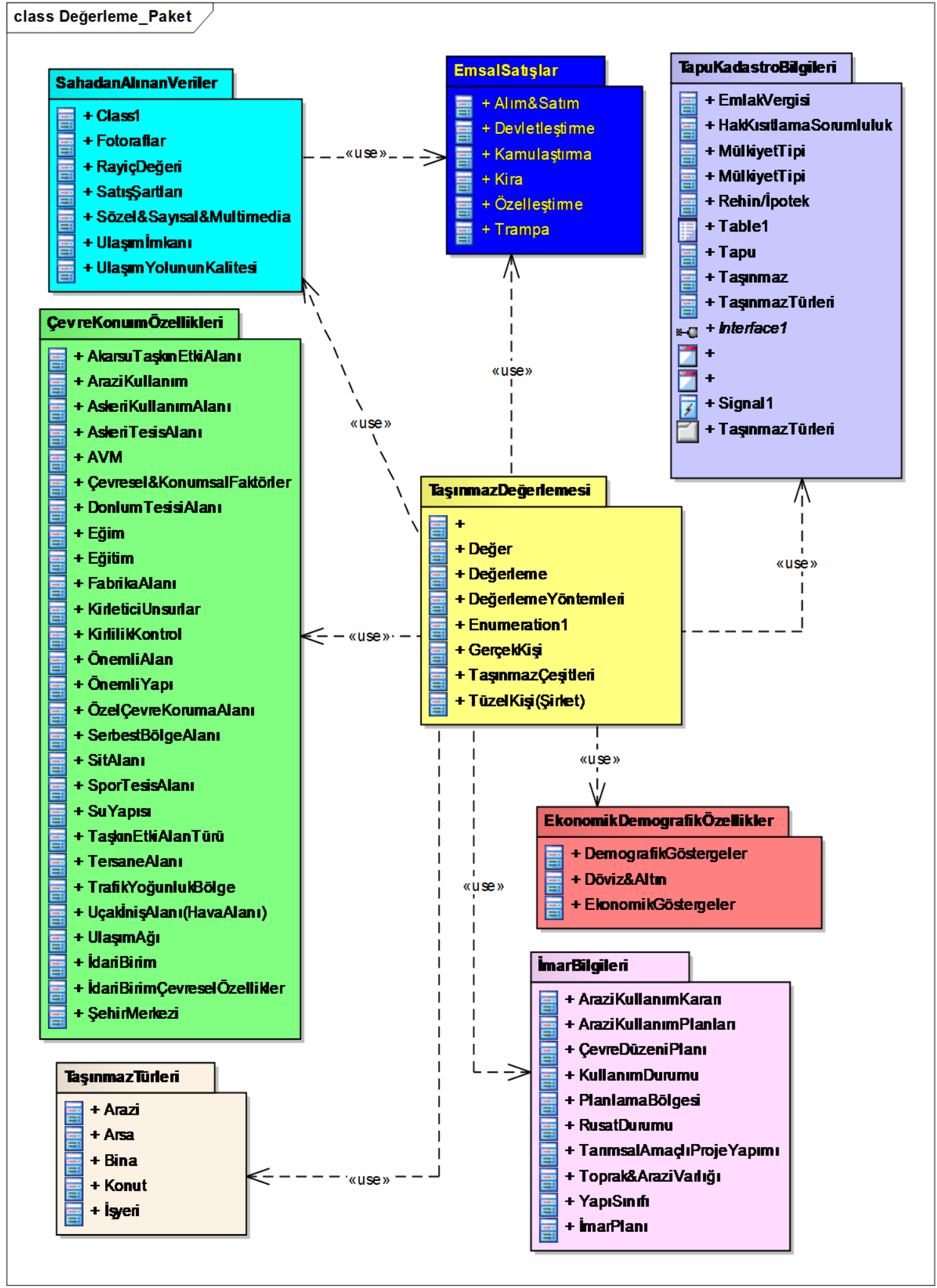

Şekil 6. Modeli Oluşturan Veri Setleri/Grupları Genel Görünümü ve İlişkileri

(Bostanc1 vd., 2012'den geliştirilmiştir). 


\section{SONUÇ ve ÖNERILER}

Sunulan teknik öneriler şu şekilde
özetlenebilir:

- Taşınmaz değerlemesi alanında gelişmis sistemlere sahip ülkelerde olduğu gibi, ülkemizde de değerleme çalışmaları sırasında ihtiyaç duyulan verilere erişilebilmesi ve çalışmaların sağlıklı bir altyapı çerçevesinde gerçekleştirilebilmesi için, taşınmaz karakteristikleri ve taşınmaz piyasasındaki gerçek alım-satım değerleriyle ilgili bilgileri içeren veritabanları kurulmalıdır. Taşınmaza ait bilgilerin ortak bir veritabanından elde edilebilmesi, değerleme uzmanlarının ihtiyaç duydukları verilere daha kısa sürede ve kolayca ulaşabilmesini sağlayacaktır.

- TKGM tarafindan kullanilan TAKBİS sisteminde taşınmazların sınıflandırılması daha sağlıklı bir yapıya kavuşturulup, çeşitlerine göre satışı yapılan taşınmazlar ve değerleri, il ve ilçe bazında güncel olarak resmi sitesinden ilan edilmelidir.

- TKGM bünyesinde yürütülmekte olan TKMP'nin değerleme dışındaki bileșenlerinde ciddi çalışmalar yapılmış ve karşılı̆g 1 alınmıştır. Taşınmaz değerleme bileşeninde ise proje ile amaçlanan ve ülkemize en uygun modelin ortaya koyulması, bu doğrultuda politika geliştirilmesi hedefi ve şehir bazlı pilot uygulamalar henüz gerçekleşmemiştir. Başlatılan bu çalışmaların daha ileri noktalara taşınması gerekmektedir.

- SPK tarafindan, UDES ve Türkiye'deki mevcut taşınmaz mevzuatı dikkate alınarak, bankalar ve diğer kuruluşlar için her taşınmaz türüne göre ayrı ayrı olmak üzere ortak bir değerleme rapor formatı geliştirmelidir. Böylece, hem ileride oluşturulmak istenen değerleme veritabanı için önemli bir başlangıç olacak ve hem de tekrarlı değerleme işlemlerinin önüne geçilebilecektir.

- Kat Mülkiyeti Kanunu'na göre bağımsız bölümlerin yüzölçümlerinin mimari projede gösterilmesi zorunlu olduğundan, mevzuat değişikliğine gerek duyulmaksızın, belediyelerce onaylı mimari projedeki listede bağımsız bölümlerin yüzölçümlerinin gösterilmesi ve TAKBİS siteminde bu konuda bir düzenleme yapılması gerekir.
- Değerleme uzmanlarına verilere erişim konusunda kanunlar çerçevesinde bazı ayrıcalıklar tanınmalı, gerekiyorsa belli ve uygun harçlar karşılığında, bir takım verilere erişimlerini kolaylaştırmak ve memur/görevli şahıslarla iletişimlerini minimuma indirip çevrimiçi olarak verilere ulaşmaları sağlanabilir. Özellikle verilerin elektronik ortamda oluşturulması ve saklanması işlemleri hızlandıracaktır. Örneğin kadastro paftaları, tapu kayıtları, imar paftaları gibi veriler çevrimiçi veritabanlarında çeşitli yazılımlar sayesinde, şifreli olarak değerleme uzmanlarına sunulabilir. Bunun için gerekli altyap1 düzenlemeleri yapilabilir. Resmi kurumlarda uygulanması gereken, çevrimiçi sistemlere geçiş süreci uzun olabileceğinden, tüm kurumlarda tek bir karar uygulanmas1 daha kısa vadeli bir çözüm olarak düşünülebilir. Böylece herkes her kurumdan eşit hizmet alabilir.

- Değerleme hizmeti veren kurum ile veriyi üreten kurumların birbirleri ile aktif bir bağının olmaması gerekir. Ancak, ülkemizde aynı kurumlar verileri üretmekte, değerlemede kullanmakta ve yine aynı kurumlar değerleme sonuçlarını kontrol etmekte ve onaylamaktadır.

- Değerleme kullanılan yazılım ve personelin milli olması gerekir. Ayrıca, sistemi devam ettirebilmek için de yetişmiş eleman şarttır. Yoksa en iyi sistem de kurulmuş olsa devamını getirecek teknik eleman olmadan sistem devam ettirilemez.

- TADES'in teknik bileşenine bakıldığında; ülkemizde değerleme çalışmaları sırasında ihtiyaç duyulan güncel ve doğru verilere erişilebilmesi ve çalışmaların sağlıklı bir altyap1 çerçevesinde gerçekleştirilebilmesi için, taşınmaz karakteristikleri ve taşınmaz piyasasındaki gerçek alım-satım değerleriyle ilgili bilgileri içeren veritabanlarının tesis edilmesi gerekmektedir. Taşınmazlara ait bilgiler sağliklı verileri içeren ortak bir veritabanından elde edilebilirse, değerleme uzmanları hem ihtiyaç duydukları verilere daha kısa sürede ve kolayca ulaşabilecekler hem de daha sağlıklı sonuçlar elde edebileceklerdir.

- Öncelikle, iyi işleyen taşınmaz değerleme sistemine sahip birçok ülkede olduğu gibi, 
ülkemiz genelinde yürütülen değerleme çalışmalarının da sağlıklı ve bütüncül bir yaklaşımla gerçekleştirilebilmesi için, oluşturulacak lider kurumun özellikle tapu ve kadastro teşkilatıyla yakın işbirliği içinde bulunması sağlanmalıdır.

- Lider kurum, değerleme çalışmalarında ihtiyaç duyulan taşınmaz karakteristikleri ve emsal satışlar veritabanlarının oluşturulması ve sürdürülmesini sağlayacak önlemleri almalidir.

- Özellikle değerleme sonuçlarının görüntülenmesi ve denetlenmesi aşamasında CBS'den yararlanılmalı, rayiç değerlerin kontrol altına alınacağı bir CBS modeli uygulamaya koyulmalıdır.

- TADES yaklaşımında değerlemeden sorumlu kurum olarak önerilen TDGM, farklı kurumların ve özel sektör değerlemecilerinin ihtiyaç duyduğu taşınmaz karakteristikleri ve emsal satışlar veritabanlarının oluşturulmasını sağlamalı ve izlemelidir. Bu veritabanları, Taşınmaz Değerleme Bilgi Sistemi (TDBS) kapsamında, diğer bilgi sistemleriyle bütünleşik bir veri modelinde ve Coğrafi/Kent Bilgi Sistemi destekli tasarlanmalıdır. Değerleme sonuçlarının kullanıcılara tebliğ edilmesi ve internet üzerinden erişim olanakları hazırlanmalıdır.

- Analiz ve modelleme çalışmalarının gerçekleştirilebilmesi için, ilk ve en önemli koşul, kuşkusuz kaliteli verilerin temin edilmesidir. Litaratürdeki farklı kaynaklardan elde edilen verilerin yanı sıra çeşitli uygulamalarda kullanılmış olan verilerin kullanılmasiyla bir veritabanı oluşturulmalıdır. Ancak verilerin, hem bu veritabanının oluşturulması, hem de istatistiksel analiz ve modelleme çalışmalarına imkân verecek kalite ve formatta olması gerekir.

- Değerleme Uzmanı için sağlam bir veri toplama sistemi mevcut olmalidir. Verilerin kaydedilmesi elle giriş yöntemlerinden ziyade Coğrafi Bilgi Sistemlerini de (CBS) içeren bilgisayar destekli değerlemeye olanak sağlayan gelişmiş veritabanlarının oluşturulması sağlanmalıdır. Mülk verileri niceliksel (yani arazinin büyüklüğü, boyutları, inşaat şartları) ve/veya niteliksel (fiziki durum, özellik veya iyileştirmelerin arzu edilebilirliğinin değerlemesi) olabilir. $\mathrm{Bu}$ alanda sistemleri gelişmiş birçok ülkede değerleme veri bankaları ulusal, federal, devlet veya yerel hükümet yasalarının hâkim olduğu alanda, mülkiyet hakkını veya bir arazi üzerindeki menfaatleri tanımlayan arazinin kullanım kayıtları, örneğin tapular, devir/temlik belgeleri ve satış bilgileri etrafında kurulmuştur (SPK, 2006).

\section{KAYNAKÇA}

Açlar, A., Çağdaş, V., (2008). Taşınmaz (Gayrimenkul) Değerlemesi, TMMOB Harita ve Kadastro Mühendisleri Odası, ISBN 975-395-551-0, Ankara, $500 \mathrm{~s}$.

Başer, V., (2014). Kıyı ve Denizel Alanlarda Arazi Yönetimine Yönelik Sorunlar ve Çözüm Yaklaşımları, Karadeniz Teknik Üniversitesi, Fen Bilimleri Enstitüsü, Doktora Tezi, Trabzon, $221 \mathrm{~s}$.

Bostanc1, B., İnan, H. İ., Çete, M., Geymen, A., Erdem N., (2012). UML tabanlı taşınmaz değerleme modeli tasarımı: konut değerleme örneği, II. Arazi Yönetimi Çalıştayı, 21-22 Mayıs, İTÜ, İstanbul.

Çağatay, U., (2008). AB Sürecinde Türkiye'de Bilgi Yönetimi ve Konumsal Bilgi Sistemleri İle Taşınmaz Piyasalarının Analizine İlişkin Bir Model Tasarımı, Dokuz Eylül Üniversitesi, Sosyal Bilimleri Enstitüsü, Doktora Tezi, İzmir, 327 s.

Çağdaş, V., (2007). Türkiye İçin Bir Emlak Vergi Sistemi Tasarım Modeli Önerisi, Yıldız Teknik Üniversitesi, Fen Bilimleri Enstitüsü, Doktora Tezi, İstanbul, $226 \mathrm{~s}$.

Çete, M., (2008). Türkiye İçin Bir Arazi İdare Sistemi Yaklaşımı, Karadeniz Teknik Üniversitesi, Fen Bilimleri Enstitüsü, Doktora Tezi, Trabzon, $243 \mathrm{~s}$.

Çete, M., (2014). Kadastro 2014'ün ve Türkiye kadastrosunun geleceği, www.hkmo.org.tr/resimler/ekler/883ddd7 84c6d398_ek.pdf, (E.T.: Ekim 2015).

Değirmenciler, E., (2008). Kentsel Gelişim Sürecinde Türkiye'de Gayrimenkul Değerleme Sorunları ve Çözüm Önerileri, Kocaeli Üniversitesi, Sosyal Bilimler Enstitüsü, Yüksek Lisans Tezi, Kocaeli, $103 \mathrm{~s}$.

Hacıköylü, C., (2009). Emlak Vergisinde Değerleme Sorunu ve Değer Tespitine 
İlişkin Öneriler, Anadolu Üniversitesi, Sosyal Bilimler Enstitüsü, Doktora Tezi, Eskişehir, $211 \mathrm{~s}$.

HKMO, (2012). Sempozyum Bildiriler Kitab1, Arazi Yönetiminde Taşınmaz Değerleme ve Kadastro Sempozyumu, ATO Uluslararas1 Kongre ve Sergi Saray1, HKMO\&TKGM, 22-23 May1s, Ankara, $240 \mathrm{~s}$.

İnan, H., (2010). Arazi İdare Sisteminin Tarım Bileşeni Olarak Konumsal Veri Modeli Geliştirilmesi, Karadeniz Teknik Üniversitesi, Fen Bilimleri Enstitüsü, Doktora Tezi, Trabzon, $199 \mathrm{~s}$.

Jahanshiri, E. B., (2011). A Review of Property Mass Valuation Models, Pertanika J. Sci.\&Technol. 19, ss: 23-30, ISSN: 01287680, University Putra Malaysia Press.

Köktürk, E., Köktürk, E., (2015). Taşınmaz Değerlemesi, Taşınmaz Hukuku - İmar Hukuku - Değerleme Yöntemleri, Seçkin Yayınc1lı, 2. Baskı, Ankara, ISBN 978975-02-312, $1304 \mathrm{~s}$.

Nişanc1, R., (2005). CBS ile Nominal Değerleme Yöntemine Dayalı Piksel Tabanlı Kentsel Taşınmaz Değer Haritalarının Üretilmesi, Karadeniz Teknik Üniversitesi, Fen Bilimleri Enstitüsü, Doktora Tezi, Trabzon, $230 \mathrm{~s}$.

Page-Jones M., (2002). Fundamentals of ObjectOriented Design in UML, AddisonWesley, Dorset House Publishing, New York, ISBN: 020169946X.

Pagourtzi, E. and Assimakopoulos, V., (2003). Development of real estate evaluation system with the use of G.I.S. technology, In 10th European Real Estate Society Conference, ERES: Conference, Helsinki, Finland.

Rissi S., B., (2013). İsviçre ve Almanya'da kentsel dönüşüme yönelik taşınmaz değerlemeleri, TMMOB Harita ve Kadastro Mühendisleri Odasının düzenlediği 1. Uluslararası Kentsel Dönüşüm Sempozyumu, 7-8 Ekim, Ankara.

SPK, (2006). Sermaye piyasasında uluslararas değerleme standartları hakkında tebliğ eki, Seri: VIII, No: 45, http://www.spk.gov.tr, (E.T.: Aralık 2015).
Susar, Ö., (2007). Malezya'da Gayrimenkul Değerleme: Yurt Dişı Geçici Görev Raporu, TKGM, Ankara.

TDUB, (2011). Türkiye Değerleme Uzmanları Birliği TUGDES taslak çalışması, Versiyon 1, http://www.tdub.org.tr/images/pdf/tugdes_ taslak_metni.pdf, (E.T.: Kasım 2015).

TKGM, (2014). TKMP-Gayrimenkul Değerleme Bileşeni Pilot Uygulama Taslak Tamamlanma Raporu, TKGM Kadastro Dairesi Başkanlığı, 182 sayfa, Ankara.

URL_1: http://www.tkgm.gov.tr (E.T.: Kasım 2015).

Yalpır, S., (2007). Bulanık Mantık Metodolojisi İle Taşınmaz Değerleme Modelinin Geliştirilmesi ve Uygulaması: Konya Örneği, Selçuk Üniversitesi, Fen Bilimleri Enstitüsü, Doktora Tezi, Konya, 248 s.

Yalpır, Ş., Özkan, G., Erdi, A., (2002). Kentsel alanlarda taşınmaz değerlerinin belirlenmesi ve Konya örneği, Selçuk Üniversitesi Jeodezi ve Fotogrametri Mühendisliği Öğretiminde $\quad 30 . \quad$ Y1l Sempozyumu, Konya.

Yıldız, Ü., (2014). Gayrimenkul Birimlerinde Kitlesel Değerleme Uygulamaları ve Türkiye İçin Model Önerisi, Ankara Üniversitesi, Fen Bilimleri Enstitüsü, Yüksek Lisans Tezi, Ankara, 227 s.

Yılmaz, S., (2012). Mirasa ilişkin tapu işlemlerinde yeni dönem, LEGES Hukuk Dergisi, Y1l: 3, Say1: 32. 